\title{
CHAPTER 11 \\ Challenging the Economic and Cultural Currency of English
}

\author{
NATHAN JOHN ALBURY
}

\section{INTRODUCTION}

The extensive library of scholarship in sociolinguistics - from language ideology to language practice and language policy - has proven to us in no uncertain terms that English is the world's current linguistic superpower. People study it as a second language because it promises socio-economic mobility and advancement in the global neoliberal market. Nation states around the world have responded with strategic top-down language policies whereby English is now, across all continents, a compulsory element to some extent in formative education (cf. Jenkins et al. 2011; Ricento 2015; Spolsky 2009). In the Netherlands, for example, where this chapter was written, children as young as five might start to acquire English in the classroom. This early preparation makes sense. In the Netherlands, English holds ongoing prestige as a lingua franca for European integration and cooperation. Outward-looking Dutch commercial interests are often necessarily English medium, and even tertiary education is increasingly provided through English (Gerritsen et al. 2016). The story in other societies - European or otherwise - is similar. Besides English being a linguistic pivot in the global political economy, the omnipresence and popularity of cultural exports that originate from the Anglo world - commonly, but perhaps not affectionately, referred to as the McDonaldization of society (Smart 1999) mean this is not undesired.

The purpose of this chapter, however, is to play the devil's advocate to this established view of English. It does this by exploring examples of language ideologies at the local level that are posing challenges to the high status and prestige of English in ways contextualized by local histories, socio-economics and politics. Specifically, the chapter takes us to multilingual Malaysia and bicultural New Zealand as two divergent but nonetheless related case studies. Their divergence is perhaps most obvious. Malaysia, at a crossroads in Southeast Asia, hosts a Malay-speaking majority and a plethora of heritage languages spoken by its Chinese, Indian and non-Malay indigenous minorities. However, English is the language of Malaysia's internationalized free market economy, and the exploitation of multilingual repertories is the norm. New Zealand, on the other hand, is a predominantly English-speaking nation in the South Pacific, but where the 
indigenous te reo Māori language has become so displaced by English that today language revitalization - and with it Māori cultural revitalization more generally - is state policy. While these local sociolinguistic contexts are clearly different, Malaysia and New Zealand are united by the fact they are both former British colonies. In both societies, the English language was - long before it had acquired its current status as the world's lingua franca imported and imposed as a language of foreign rule, of administration, and of the elite as part of the broader British colonial enterprise. This chapter will show that in the context of it being the language of both the colonizer and the global neoliberal market economy, the socio-economic and cultural currency of English is in specific cases being challenged. In the case of Malaysia, this results from socio-economic mobility being in dialectic relationship to Mandarin as the language of China's powerhouse economy, and in New Zealand from a heavy postcolonial conscience coupled with a quest to establish a non-European national identity in the South Pacific. In both cases, these challenges have been identified through an analysis of emic folk linguistic talk about linguistic diversity with youths in those countries, whereby these youths were asked to explain - $\begin{gathered}\text { their sociolinguisti } \\ \text { based on }\end{gathered}$ what they claim to know and what they feel.-about-their-sociolinguistic-envirens. To this end, it firstly pays to elaborate on what a folk linguistic approach can offer such ideological sociolinguistic research.

\section{A FOLK LINGUISTIC APPROACH}

The epistemology and methods of the folk linguistic research tradition deserve their place in the language ideology research toolkit. This is especially so if we take an expanded view of what counts as language ideology. Language ideology, particularly in the current scholarly context, is by no means confined to "capital I" ideologies that give titles to indexed doctrines such as neoliberalism or nationalism. Such "capital I" ideologies do indeed have their value and much discussion in contemporary sociolinguistics is rightly premised on the enduring impact of "capital I" ideologies. One such example for language is the Western - and often Anglo-American - monolingual assumption. This describes a social psychological bias to assume that humans and societies are inherently monolingual such that multilingual proficiencies and communities are seen to somehow disrupt the natural state of affairs (Blackledge 2000). This ideology contrasts with what I have termed the multilingual assumption that can exist outside the West where individual and societal multilingualism has long been so normative that individuals may struggle to identify their mother tongue and homogeneity is seen as the marked case (think, for example, of India, Nigeria or South Africa). The one nation-one language ideology is another well-traversed "capital I" ideology in sociolinguistic literature. This describes the politics of tying each nation or ethnic group to a single language in the modernist interests of social cohesion, governmentality and ethnolinguistic consistency (Wright 2003). This ideology, albeit it manifests in locally nuanced ways in response to local political interests and pressures, helps to explain for example why the French language is emphatically heralded as a quintessential character of French nationhood, and why China seeks to unite its people including the thorny case of democratic Cantonese-speaking Hong Kong - though Mandarin.

However, language ideologies need not all be "capital I" ideologies that operate at macro-levels nor necessarily assume membership in large numbers. They can also include more localized senses of commonsense about the sociolinguistic world. These "little i" ideologies have consolidated their position in scholarship through theoretical perspectives 
on language ideology, such as from Rumsey (1990), who sees language ideology as "shared bodies of commonsense notions about the nature of language in the world" (346) and Blommaert (2006) who sees it as "the unspoken assumptions that, as some kind of "social cement", turn groups of people into communities, societies, and cultures" (510). In definitions of language ideology such as these, the focus lies not just on how people feel, in evaluative terms, about the sociolinguistic world around them akin to language attitudes. Instead, the focus also encompasses local truths, claims of logic, commonsense or fact about language, even if these lack empirical basis (think, for example, of parents claiming that bilingualism would impede the cognitive development of their children and in turn avoid raising their children bilingually). Where these claims are shared, even if only by a small collective, and contribute to a common understanding about what is right and what is normal, then they can be considered (part of) an ideology. Crucially, this means that ideology can be explicitly seen as encompassing what is believed to be true about the sociolinguistic world, not just what is believed to be desirable (Albury 2017b).

This is where the link between folk linguistic talk and language ideology becomes powerful. Folk linguistics is concerned on the one hand with how the world of language is constructed by people in the community through their own epistemic terms and on the other hand with how they feel about different linguistic phenomena (Preston 2005, 2011). Whereas the latter focus is synonymous with language attitudinal research, the former is a postmodern notion that accepts that knowledge held and articulated by non-experts may be rooted in cultural paradigms and can complement or inform the work of researchers (Canagarajah 2005). The point is not whether what people claim to know as truths or common sense about language is empirically reliable. Instead, the point is Foucauldian (Foucault 1980) whereby knowledge is legitimate if it is deemed as such by those who hold it and rely on it to make sense of the world around them. What people might know about sociolinguistics - even if this knowledge is backed up by science - does after all structure their engagement with the sociolinguistic world. It even informs how people solve local language issues, such as in the home and in classrooms, and this postmodern view on knowledge and decentralized authority on knowledge is the fodder of academic inquiry into, for example, family language policy (cf. King et al. 2008; Li Wei 1994) and educational linguistic anthropology (cf. Hornberger 2002; Johnson 2009). Where knowledge that guides language choices and decisions is shared by some collective, then this folk linguistic knowledge can be considered as contributing to a language ideology. This makes folk linguistic knowledge worth investigating in the name of language ideology.

On this epistemological basis, I have investigated - in two distinct but theoretically related projects - how youths in Malaysia and in New Zealand understand and explain in folk linguistic terms their multilingual lives and multilingual societies (with the sociolinguistic background to the cases of Malaysia and New Zealand to be provided later in this chapter). In both contexts, English is the language of the colonizer, but also the language of international connectivity and the globalized market economy. However, in New Zealand this came about through settler colonization, as sociological theory explains (Veracini 2014), whereby the objective was that the people, culture and language of the colonizers would replace their indigenous counterparts. Malaysia, on the other hand, did not see a British population become its majority, nor the uniform imposition of British culture, but colonization especially amounted to the exploitation of Malay land. Nonetheless, the focus in my research lay on identifying and analyzing shared knowledge that may be constitutive of language ideologies, or even of epistemologies if shared 
knowledge contributes to fundamental world-views vis-à-vis the role, place and nature of language. The folk linguistic orientation meant that people who had trained in linguistics whether academically or through their occupation - were not eligible to participate. In both cases, participants were university students between 18 and 25 years pursuing undergraduate degrees in a range of disciplines, including the natural sciences, medicine, business, literature and law.

In the case of New Zealand, 1,297 university students from across New Zealand studying at the University of Otago in Dunedin, including - on the basis of self-identification 1,090 Pākeha (New Zealanders of European descent), 54 Māori and 153 Māori/Pākeha students, responded to a folk linguistic questionnaire about the Māori language. The questionnaire solicited quantitative and qualitative data to ascertain levels of agreement and disagreement to a range of epistemic claims about the nature, purpose and success of language policy - led by government but advanced in the community - to revitalize the Māori language since its near eradication by British colonial forces and their legacy. This meant proposing key facts about language revitalization - as they have been established in the academic literature but also about Māori in New Zealand - and soliciting and quantifying levels of agreement to epistemic claims, supplemented by qualitative free text whereby the students could explain their (dis)agreement in folk linguistic terms in respect to specific proposed facts. The questionnaire also ascertained the language policy ambitions of New Zealand youth in terms of what the revitalization of the Māori language ought to achieve including in respect to the status and vitality of English as New Zealand's dominant language (for more detail on methodology and findings, see cf. Albury 2018a, 2016a, 2016b; Albury and Carter 2017; Albury 2015).

In the case of Malaysia, I held group discussions with students at universities across the country, including in Kuala Lumpur, Penang, Kota Bharu, Kuala Terengganu on peninsula Malaysia, as well as in Kuching and Miri in the state of Sarawak on Borneo Island. A total of 24 group discussions were held, including 10 with Malay students, 9 with Chinese students and 5 with Indian students, with each group comprising 4 to 6 participants. Grouping along ethnic lines responded to local politics and cultural norms, especially backgrounded by ethnicity being the single most important marker in Malaysian society and a basis for Malaysian social organization (Noor and Leong 2013). In these semi-structured discussions, the students explained multilingual life and society in Malaysia through their own epistemic lenses relying on their own epistemologies of language, their language ideological frameworks, and what they knew as fact and commonsense about their sociolinguistic lives, communities and language policy (for more detail on methodology and findings, see cf. Albury 2018b, 2018c, 2017a, 2019, 2020). In this case, this also included prompting the students from each ethnic group to discuss not only how they feel about Malaysian being a multilingual state, but how their own heritage languages - and multilingualism more generally - are perceived by the other ethnic groups. This meant relying on the social and discursive elements of theory of mind from psychiatry (Sodian and Kristen 2010) and applying them to sociolinguistic research. This helped to clarify the ideological environment with more nuance and complexity by seeing language ideology - as it affects discourses and social relations - as also including how people feel or hypothesize they are positioned by others in that hierarchy (which, in turn, they might rely on when engaging with the outside world).

Drawing on data and analysis from these two research projects, this chapter will now show how - through folk linguistic talk and analysis of it - the status of English is being challenged. In particular, the chapter will show that Mandarin is challenging English - in 
ideological terms - as the language of socio-economic mobility in Malaysia. In the case of New Zealand, the chapter will show that postcolonial guilt and the construction of a non-British identity in a former British colony in the Pacific is allowing te reo Māori to equal or surpass English in terms of cultural legitimacy and authenticity.

\section{MALAYSIA: WHERE MANDARIN CHALLENGES THE ECONOMIC CURRENCY OF ENGLISH}

Nestled at a cultural and linguistic crossroads in Southeast Asia, Malaysia's international image is one of harmonious multiculturalism and multilingualism. This has been useful fodder in the country's Malaysia, Simply Asia tourist brand where ethnic Malays, Chinese and Indians form an egalitarian melting pot. In real terms, however, Malaysia's linguistic and ethnic diversity is plagued by an institutionalized hierarchy. Rather than celebrating cultural egalitarianism, Malaysia is an ethnocratic state that seeks to place power and privilege with ethnic Malays, with Islam as their religion, and with Bahasa Malaysia as their heritage language. This ideology is known as Ketuanan Melayu (Goh et al. 2009). For context, some history is needed.

Malaya, as it was formerly known, fell into British colonial hands when the British acquired trading ports in Western Malaya from Dutch imperialists in 1824. British forces gradually superimposed their own administration whereby the Pangkor Treaty of 1874 was a watershed turning point in British-Malayan relations. In response to conflict over the control of tin mines, the treaty saw that a British resident would be attached to each local court and be mandatorily consulted - and whose advice would be mandatorily enacted on all matters besides Islam and customs (Andaya and Andaya 2016). This, it was argued, would show the local Malays "good government and enlightened policy" (Sadka 1968). And so the expansion of British control of British Malaya took hold. The British welcomed the ongoing arrival of Chinese immigrants who had sought new lives and opportunities in the region, especially in what is now Western Malaysia and Singapore. Whereas the British branded local Malays in racist terms as unable and unwilling to contribute meaningfully to the colonial economy, they saw the Chinese as entrepreneurial and admired their business acumen. Waves of Chinese immigration were therefore largely uninterrupted. The Malays were instead typically relegated to agriculture in impoverished rural areas. The British also facilitated migration from Southern India - especially from Tamil Nadu - as a source of labour for the rubber plantations. These Tamils, the British felt, were accustomed to British rule and were therefore easy to manage, making them ideal labourers (Andaya and Andaya 2016). British colonial rule persisted until independence was declared in 1957.

Besides instilling a divide and rule policy whereby these three main ethnic groups were deliberated by socio-economic lines, the British had inadvertently created a plurilingual society. The Chinese had brought a plethora of languages with them, including Cantonese, Hokkien, Hakka, Foochow and Teochew, and the Indian migrants had brought not just Tamil, but also - to a smaller degree - languages such as Malayalam and Telugu (Zhou and Xiaomei 2017). By the time of independence, and in the absence of the Chinese and Indian diasporas returning home as had been anticipated, Malaysia had become an unexpectedly multilingual society. Leading this plurality in ideological, practical and economic terms was, however, English. Finding the nation's feet meant reclaiming Malaysia as quintessentially Malay, and therefore doing away with the linguistic heritage of the colonizers. It also meant reminding the now-well-established Chinese and Indian 
minorities - who now make up around 25 per cent and 8 per cent of the population, respectively - that ethnic Malays are the rightful owners of the land (Hamayotsu 2014). This, coupled with Ketuanan Melayu, would be the backbone of Malaysian nation-building and was in large part a political response to the Chinese community having come to dominate the Malaysian economy. That is to say, the Chinese had become the backbone of the Malaysian economy and had surpassed the Malay community in socio-economic development, but the Malays would seek to address this by asserting political power in the absence of holding economic power. Bahasa Malaysia would be the sole national language, and language rights from the Chinese and Indian minorities would be restricted to heritage language-medium primary-level education. From there, students would be expected to assimilate to Bahasa Malaysia. In practice, however, non-Malays have not assimilated. Instead, Malaysia remains intensely multilingual as a society. The Indian and Chinese minorities have largely retained their heritage languages, and shift away from them is sooner to Mandarin, in the case of the Chinese community as a linguistic unifier for an otherwise linguistically heterogeneous ethnic group. The Indian communities, however, sooner shift to English as a language of prestige whereby Indian heritage languages are commonly devalued in local Indian discourse and ideology, much to the lamentations of Indian youth (Albury 2018b).

Malaysia has not successfully rid itself of the prestige that became attached to English in the Malaysian psyche, despite fervent political attempts to do so. The English language, and the central position it had assumed in government, the economy, and in education that had been designed and managed by the British, was an unwelcome reminder of colonial oppression. Building the contemporary Malaysian state would on the one hand mean shedding these colonial remnants (Ridge 2004; Noor and Leong 2013). English-medium education would be gradually phased out; however, the rise of English as an international lingua franca also meant that English had become the language of Malaysia's capitalist free-market and internationalized economy. For pragmatic reasons, nationalist fervour against English needed to be balanced against an instrumental need to maintain high proficiencies in English within Malaysia for the benefit of Malaysian economic development. Recognizing this, the government advanced policy so that mathematics and science would be taught in English at Malaysian schools; however, this has since been subject to an ideological rally between instrumentalists and nationalists leading to ongoing policy back-flips (Gill 2013). Government-funded universities are still generally English medium, despite laws to the contrary, whereby high-level English proficiency is a prerequisite for success in tertiary education (Gill 2005). Added to this, foreign tertiary education providers have established onshore campuses - such as Curtin, Monash, Swinburne (Australia) and Reading, Southampton, Heriot-Watt and Nottingham (United Kingdom) - that offer their foreign, English-medium curricula. Malaysia's international image vis-à-vis commerce and investment also remains staunchly English in dialectic relationship to its capitalist outlook, whereby even the Malaysian Investment Development Authority advertises Malaysia to potential investors as enjoying "wide use of English, especially in business, legal and accounting practices based on the British system" (2019).

English has also firmly cemented its prestige within Malaysian society beyond its economic instrumentality. Coluzzi (2012) has concluded that English holds even greater status than Bahasa Malaysia. For example, social media is by far an English-medium domain, for communication both within and between ethnic groups, and arguably with the vicarious intention to attract an international audience to social media posts (Albury 2018c). 
Offline, if English itself is not being used, then code-switching and mixing with English is more normative than monolingual dialogue in Bahasa Malaysia alone (Coluzzi 2012). In my research with Malaysian youths, English was reported by all ethnicities as a key language for communication with friends, as an important home language for Indians and also as important or more important than other languages among Indians and Chinese when undertaking daily interactions, such as shopping or running errands (Albury 2018c). What is more, a new local variety of English referred to as Manglish has become a default medium for communication in informal domains. Although 'Manglish' is the term used by many speakers, it can for many carry connotations of being low status, broken English and a variety to be avoided. Manglish will be used in this chapter, as this is how research participants referred to it. In any case, Manglish can be considered a World English and especially amounts to switching to English at the lexical level. However, some grammatical features also characterize Manglish, such as removing agreement between verbs and their subjects, and rendering non-countable nouns countable through plural suffixes (Govindan and Pillai 2017). My research also showed that participants from across the ethnicities hasten to note that their language repertoires may indeed be multilingual, including Bahasa Malaysia, English and a heritage language in the case of the Chinese and Indians, but that Manglish typifies their daily interactions. This even provides them, from their folk linguistic perspective, essential proof of their contemporary Malaysian linguistic citizenship (Albury 2020).

I have found, however, that although the prestige and status of English in Malaysia is well-documented, it does not go unchallenged. Instead, Malaysian youths in the case of my investigations attached prestige and status to Mandarin such that it challenges English as a language of perceived socio-economic mobility. This has to do in large part with the capital associated with proficiency in Mandarin in the context of the booming Chinese economy and of the economic successes of the Chinese community in Malaysia which outperforms its Malay and Indian counterparts (Yow 2017). However, its genesis is also found in the fact, as briefly noted earlier, that the heterogeneous Chinese community has instilled Mandarin as its lingua franca, rather than Bahasa Malaysia. Naturally, unifying the community by way of a single language serves political ends in the face of Malay ethnocratic politics and helps to articulate Chinese resistance to policies and laws based on ethnic privilege rather than on meritocracy. However, a specifically Chinese epistemology of language has also sustained the local status of Mandarin. Although Mandarin is not a language of the historic migration to Malaysia, a Chinese world-view sees Mandarin as the single bona fide mother tongue of all ethnic Chinese people, regardless of actual proficiency in the language and regardless of other Chinese varieties being first languages. This leads to culturally situated perceptions that Chinese heritage languages in Malaysia, such as Cantonese and Hokkien, are simply dialects of Mandarin (albeit this is not supported by empirical evidence), and that ethnic Chinese are bounded by a duty to learn Mandarin as their mother tongue, even if later in life (Albury 2020, 2017a).

The sociocultural prestige of Mandarin for Chinese is clear, but it is this in combination with the socio-economic independence of the Chinese community that means Mandarin begins to challenge English. The community has acquired sufficient wealth to by-pass Malaysia's strict language-in-education laws - that see education beyond the primary level as only available in Bahasa Malaysia - by establishing its own private network of Mandarin-medium secondary schools. In response, the government legislated that attending a non-Malay secondary school precludes entry to Malaysian public universities. Again, the Mandarin-speaking community can often sidestep this policy by sending their 
students to private institutions, to foreign universities with local campuses or indeed abroad to universities ranked more highly than Malaysian intuitions (Pyvis and Chapman 2007). Chinese wealth has also established a socio-economic class that is, in large part, Mandarin-speaking given the specific success of the ethnic Chinese community. Indeed, Chinese students in my research reported to predominantly use Mandarin, and to a lesser degree a Chinese heritage language, with their friends, which in turn suggests that their friendships are largely only with other ethnic Chinese (Albury 2018b). Ultimately, this means that many in the Chinese-Malaysia community live in parallel to the rest of Malaysia. Their education is often with other Chinese people, leading to friendships and relationships with other Chinese people, and their socio-economic advantage leads them to enter networks that are populated predominantly by other Chinese that can often be traced to Chinese-medium education (Yow 2017; Phooi-Yan Lee and Ting 2016). In cases where Chinese wealth manifests in business ownership and employment opportunities, or with workplaces that are predominantly Chinese, then the status and instrumentality of Mandarin in Malaysia is elevated and occupies a status otherwise held by English.

This is not just speculation, but recognized by local Chinese, Malay and Indian youths. Rather than expressing indignation or being despondent about the hegemonic Malaysian language policy that strips Chinese-Malaysians of their language rights, they argued that Mandarin (and notably not English) is the logical national language, but is not simply because it is "quite tough to read and write", because "our staff from government is Malay. They can't speak Mandarin" and because having Bahasa Malaysia as the national language instead of Mandarin is "a way to not let the language [go] extinct". They do not feel the hegemonic impacts of Malaysian language policy because they are oftentimes not subjected to policy anyway which, as described earlier, results from a Chinese sociology of socio-economic networks and creates a confidence about the indispensability of Mandarin. This wealth, and the preeminence of the Chinese in the Malaysian economy, renders Mandarin - to their minds - the logical national language for Malaysia, all things being equal. Chinese-Malaysians therefore noted that learning Mandarin is popular among non-Chinese Malaysiansin order to advance oneself socio-economically in Malaysia and to enjoy the same economic privileges as the Chinese. For example, Chinese students explained, "Malays, actually, they need Mandarin", and in arguing this they implied that Mandarin is no longer a language in the margins, but an essential element - in direct contradiction to nationalist Malay policy and rhetoric - in the operation and successfully functioning of contemporary Malaysia. This is further elucidated in the following dialogues from group discussions:

Researcher: How do you think they [Malays and Indians] feel about Mandarin?

Student 3: As an opportunity because most businesses in Malaysia are, like, owned by Chinese, so if you know the Chinese language, you have, like, greater advantage.

Researcher: Why do they learn Mandarin?

Student 4: Because they are living in Malaysia.

These sentiments were indeed reflected by non-Malays. Malay students themselves argued that beyond proficiency in Bahasa Malaysia and English, Mandarin is a new linguistic precursor to socio-economic mobility in the Malaysian economy, precisely because the balance of economic power is in the hands of Mandarin-speakers. Malay youths argued, for example, that "we want the Malay people, Malay students, to learn Mandarin. So at least we won't have trouble when we work with a Chinese company. And that way the Chinese boss treats us equally". That is to say, equal opportunity in Malaysia 
was seen as achievable through Mandarin, parallel or perhaps even beyond the existing instrumentality of English, because it is the language of those who provide and regulate access to employment. To this end, the enrolment of non-Chinese students in Mandarinmedium education is indeed increasing (Malaysiadigest.com 2015; Yin 2015).

However, it is also the international rise of China in global economics and politics where Mandarin is the state language - which means English is challenged by Mandarin in ideological terms. Chinese-Malaysian students explained that Malaysians need to learn Mandarin as the language of Malaysia's future and economic interdependencies. They argued, for example, that "Mandarin is important because the companies that are hiring us want Chinese speaking people. Because Chinese, like China, is becoming a global superpower". Some added that it is also for this reason that the enrolment of Malay and Indian students in Mandarin-medium education is increasing, suggesting that "their parents think that there is a need for their child to master this language not only as a Malaysian himself, but also for international purposes when you have to work with China in the future". The students, whether through experience or on the basis of discourse, see an increasing relevance of China to the local economy and the commercial opportunities that are made available with China. Mandarin, not English, is the language of those opportunities.

This is not to say that English has been stripped of its prestige. It is to say, however, that economic and political developments in Malaysia - and in the Asian region more generally headed by "China's spectacular development" (Bishop 2018) - are probably rebalancing language ideologies in Malaysia. English is no longer the single linguistic provider of socio-economic advancement or international mobility for Malaysians. The wealth of the Malaysian-Chinese community, plus the rise of the Chinese economy internationally, means young Malaysians are attaching prestige and instrumentality to Mandarin parallel to English - in a way that potentially rivals English locally - at least in ideology, if not yet in practice.

\section{NEW ZEALAND: WHERE MĀORI CHALLENGES THE CULTURAL CURRENCY OF ENGLISH}

In the case of New Zealand, I have found that it is not the socio-economic instrumentality of English that is being challenged, but its local cultural prestige and authenticity in the wake of, and within social consciousness of, British colonial atrocities. By definition, New Zealand is today a bicultural state. Governance is, in theory, subject to negotiation between indigenous Māori tribes and the British Crown. The British Monarch is the official head of state, and the Crown is represented by the New Zealand government (Orange 2011). The Treaty of Waitangi - the founding document that sets out the relationship between Māori and Pakeha (European New Zealanders) - affords Māori self-determination visà-vis Māori taonga (treasures, or cultural and physical possessions) (Toki 2017). Again, this promise has often only been theoretical in its application. Failure of the Crown to comprehensively afford self-determination was a precursor to establishing the Waitangi Tribunal to hear Māori grievances vis-à-vis the Māori governance of Māori affairs that the treaty assures, including of natural resources and the cultural heritage. The relationship between Māori and the Crown has therefore been a defining factor in modern New Zealand history and in building New Zealand as an independent nation within the broader Commonwealth of Nations. In this context, matters of language, and especially 
of the survival and place of the Māori language vis-à-vis English, have been subject to vexed social policy processes.

Initially, British colonization of New Zealand, coupled with a sense of European superiority, all but wiped out the indigenous te reo Māori. The story is one that parallels that of other Indigenous languages that were suppressed across the British empire with the intention of assimilating Indigenous peoples to British culture and values. From around the mid-nineteenth century, New Zealand policy was indeed to anglicize the Māori, and this fostered wholesale language shift from te reo Māori monolingualism, to te reo Māori/English bilingualism and eventually to English monolingualism among the indigenous population (Waitangi Tribunal 2011; Albury 2016a). The 1880 Native Schools Code allowed for the physical punishment of Māori children if caught speaking their Indigenous languages on school grounds, and the country's pepper-pitting policy required that urbanized Māori live in English-speaking neighbourhoods with the objective of interrupting intergenerational transmission of their language (Davey and Kearns 1994). The notion was a modernist European one backed up by racist ideas of social Darwinism whereby the modern nation state needed to be monolingual, and that monolingualism would necessarily be in English as the language of those seen by the British imperialists as the superior of the two groups. By 1979, fewer than 100 children had any high-level proficiency in te reo Māori (Waitangi Tribunal 2011).

Parallel to a global shift in consciousness towards minority peoples subsequent to the world wars (Todal 2003), a sense of postcolonial guilt settled in the white New Zealand psyche. This consequently transpired in New Zealand state policy. To cut a long historical story short, a Māori cultural renaissance took place and sought "primarily [to restore] Maori sovereignty over the lives of Maori people" (Van Meijl 2006). White perspectives of the Māori softened when reflecting upon the losses Māori suffered in the first and second world wars in the name of the British Crown (New Zealand History Online 2012). Māori - the very people the British had imperialized by force - had joined the fight against imperialism in Europe and Asia and died for their European peers. A turn in national psyche towards the Māori, although of course not universal, prompted a national policy shift away from suppressing Māoridom. Modern New Zealand would seek to protect and promote Māoridom as a matter of Indigenous self-determination and of postcolonial reconciliation, and to correct previous injustices. This meant seeking to restore what had been eroded by racist social Darwinism, including te reo Māori. The state began funding the grass-roots kurakaupapa Māori-medium education established by Māori community themselves as a protest to Pakeha hegemony, and the language became an official language of the country in 1986. This arose from a Waitangi Tribunal finding that the language is taonga, and therefore must be subject to governance by Māori themselves within the framework of Māori self-determination, whereas Crown management of it - whether through oppression or otherwise - was a constitutional violation (Benton 2017). The Tribunal (2011) only further strengthened its position in 2011 when it found that

The language is clearly a taonga of quite transcendent importance to Māori, and few other taonga could rival its status . . . the Crown's protection of it clearly needs to accord with Māori preferences - and, indeed, be determined in large measure by Māori ideas. (442)

The point for this chapter is that although the language has been positioned in recent years as a property and responsibility of Māori, my research shows that Pakeha youths reject this. State policy on te reo Māori, guided by Waitangi Tribunal rulings on it, has 
positioned the language in ideologically neotraditional terms whereby the language is for and by ethnic Māori, whereby language revitalization - whether in schools or in communities - does not require Pakeha participation beyond showing goodwill to Māori linguistic endeavours (de Bres 2011). This aligns with sociolinguistic theorizing that suggests that Indigenous languages need to at least be tolerated by the ethnic majority to be successfully revitalized (May 2003). To my mind, this presupposes that an ideology that exceeds tolerance may be unthinkable and that the ethnic majority necessarily sees an Indigenous language as a threat, whether to culture or to social cohesion. This is not unfounded, as it has clearly been the case, for example, in Norway vis-à-vis the Sami languages and in Japan vis-à-vis Ainu (Hiss 2013; Yotsumoto 2019). I argue, however, that this may be the opposite of the ideologies held by Pakeha youth in my research. They instead saw te reo Māori as intrinsic to their sense of New Zealand social citizenship and national identity, and even as authentic New Zealandness in respect to other nations. In my research, they did not attach such legitimacy and authenticity to English in matters of interethnic identity, such that te reo Māori - rather than English - appears to construct a sense of postcolonial national self. Rather, Pakeha youth saw te reo Māori as a matter of biculturalism whereby it constitutes cultural and identity property of Māori and Pakeha alike alongside, but not superseded by, English. In fact, 70 per cent of Pakeha in my research argued that te reo Māori indexes their own New Zealand identity, even if they are not proficient in it, and 95 per cent rejected it as only indexing Māori ethnic identity (Albury 2016a). That is to say, the vast majority did not see English as the single legitimate linguistic index of their collective citizenship as contemporary New Zealanders, even though it is their first language and high-level proficiency in te reo Māori is rare. They explained, for example, that "regardless of ethnicity, I believe New Zealanders collectively have a right to it" whereby English holds no higher ideological status than te reo Māori in terms of identity.

This, I believe, in part has its genesis in postcolonial guilt. For example, Pakeha youths argued that Māori language revitalization is simply indispensable. They explained that "if we lose their language, we lose our history" whereby our history includes suppression and te reo Māori ought to be revived for the purposes of contemporary nationhood (Albury 2018a). Others more adamantly argued that the status of English must be reduced on the basis of moral conscience, arguing

colonialism has been worse in the last 30 years and in the 100 years previous to it. Furthermore, the passing of native speakers and the loss of traditional communities and identities which fall apart due to financial pressures in an increasingly unequal society contribute to the risk of losing te reo.

Around 45 per cent also claimed that English place names ought to be eradicated where Māori place names had existed but were erased by colonialists, arguing, for example, that "places that have a historical or significant relation to Māori should have an official Māori name". Another 11.5 per cent argued that place-naming should be rebalanced to reflect the biculturalism of the country that arises from the colonial past, but configuring this biculturalism so that English is not superior to te reo Māori (Albury and Carter 2017). Surprisingly, however, only 27 per cent agreed that that te reo Māori should immediately be taught before other foreign languages, and only a few of those students felt that it should be made as compulsory in the school system as English. These students rejected the colonial hegemony of English and the suppressive policy of English monolingualism enacted by their ancestors to explain that "Pakeha should grow up bilingual too" and "I 
find it offensive when people think that as a NZ European I would have no interest in the language initially spoken in the land that I come from". However, the vast majority of other Pakeha did argue that mandatory te reo Māori study should indeed be introduced, but only once the teacher workforce is adequately trained to implement such policy. This would ensure that the language is taught as effectively as English.

Building on this, others even argued that te reo Māori - and not English - represents contemporary New Zealand citizenship and is the bona fide linguistic index of New Zealand on the international stage. This, I believe and drawing on insights from Belich (2001), finds its genesis - although no doubt related the postcolonial guilt - in a quest to establish a unique New Zealand identity that does not rely exclusively or necessarily on the legacy of being British. In doing this, te reo Māori is positioned as just as or more culturally authentic and legitimate than English, including among Pakeha. For example, they argued that the language "helps to invigorate a unique national identity", "defines national identity" rendering it "good for tourism", and that "if you consider yourself a New Zealander, whether Māori or Pākeha or other ethnicity, te reo should be considered at least part of your culture". Ideas such as these generated by Pakeha might, from a political perspective, be seen as dangerous territory. After all, who are Pakeha today, whose forefathers annexed Māori land and colonized Māori minds, to now also annex the Māori language for their own personal identity purposes or to treat their postcolonial guilt? Indigenous scholar Linda Tuhiwai-Smith (1999) reminds us that "it appalls [Indigenous people] that the West can desire, extract and claim ownership of our ways of knowing, our imagery, the things we create and produce" (1). This sentiment seems to structure the state's neo-traditionalist language policy discussed earlier. However, it does not seem to be the case that Māori youths were opposed to Pakeha seeking identity in te reo Māori. To the contrary, the vast majority argued that Pakeha have a postcolonial responsibility towards the language in the spirit of interethnic reconciliation, arguing for example that "-it is important not to associate the language with only Māori but all citizens/residents of NZ as it is a sign of national pride and an acknowledgment of our history". However, this is not to say these Pakeha sentiments towards te reo Māori were unanimous. Pockets of neocolonial racist discourse nonetheless emerged, such as when Pakeha claimed that "shoving Māori down everybody's throats is the absolute worst idea, it is a complete waste of time and resources especially when more important stuff could be taught to a greater extent" and that in respect to a perceived need to revitalize the language, the "Maori are whinging about fuck all".

Nor is this to say that Pakeha have learned te reo Māori to an extent that they are balanced bilinguals. Rather, this is far from the case. The challenge the Māori language poses to English is an ideological, conceptual and esoteric one, and not necessarily an instrumental or practical one. English remained steadfastly at the centre of discourses among both Pakeha and Māori - about socio-economic mobility and international communication. Accordingly, sufficient language revitalization, Māori and Pakeha both felt, will be achieved once te reo Māori proficiency is distributed across the ethnicities, but only to a low, tokenistic level that might hardly be seen as securing language vitality (Albury 2018a). For these students, this low-level proficiency - as long as it is widespread across ethnicities - is seemingly enough to ensure te reo Māori can inform and index biculturalism and a national identity, while not interrupting their own mobility afforded by the international dominance of English which, coincidently, is their own first language. In other words, while these students did not seek to dismantle the economic currency of English of which they by chance are first-language speakers, they did dismantle the 
cultural currency of it - with reflections on postcolonial atrocities and guilt - for defining contemporary New Zealand.

\section{CONCLUSION}

Has English had its day? This is perhaps a question that the above case studies prompt us to ask. The answer, in practice, is no. There is by no means any evidence in my research discussed earlier that suggests that English has had its day. The research I have summarized in this chapter does, however, suggest that cracks have emerged in what may otherwise be seen as the ironclad universal status of English. This status, bolstered by assumptions that the status is unchallenged or at least is not challenged successfully, has occupied much of critical sociolinguistic scholarship from language and mobility, globalization and neoliberalism to language in postcolonial context (cf. Jenkins et al. 2011; Piller and Cho 2013; Phillipson 2003; Ramanathan 2005). However, socio-economic developments locally among the Chinese-Malaysian community, and internationally, as a result of the booming Chinese economy and the commercial opportunities this creates - means English in Malaysia now has to share its ideological socio-economic prestige with Mandarin. Malaysian youths did not see English as the sole linguistic provider of socio-economic advancement. Instead, they were clear in their views that Mandarin is also indispensable in Malaysia's current and future economy. Perhaps this challenge to English - whereby Mandarin is afforded at least some of the economic status that English previously held independently - is also arising in other societies that are economically intertwined with China. China is, after all, the rising dragon and

since the size of the Chinese economy reached over $\$ 10$ trillion, accounting for over $13 \%$ of the global GDP, contributing about $25 \%$ of global economic growth and becoming the largest nation in international trade of goods and second largest source and destination of Foreign Direct Investment (FDI), any influence of the Chinese economy on the rest of the world is significant. (Jin et al. 2016), 272

Sociolinguists should therefore listen to economists. The global economic structure is changing and increasingly finding clout in Mandarin-speaking China. In as far as language is capital and can be commodified, then it only stands to reason that the global linguistic ecology - in terms of language and socio-economic mobility - will respond to these economic changes. This will also be reflected in language ideologies.

The case of New Zealand, however, shows us that it is the cultural currency of English instead of its economic currency - that can be challenged. The dominance of English internationally, and as the linguistic index of globalization, has not just been an economic phenomenon but also a cultural one. Anglo-American cultural products have been exported and appropriated globally. This may take on a bitter taste in the case of ex-British colonies where the English language also indexes annexation of land, forced assimilation and the suppression of Indigenous peoples, cultures and languages. Just as the global economy has evolved, so too has the global conscience in respect to the plight of Indigenous peoples and the atrocities inflicted upon them. For English-speaking Pakeha youth, a sense of postcolonial guilt - coupled with their own quest to identify in non-British terms - meant they afforded te reo Māori greater cultural legitimacy than English for describing and defining contemporary New Zealand. Te reo Māori was upheld as the authentic language of the New Zealand territory and of its Indigenous people. It was by no means upheld as 
economically more instrumental than English, but it had won from English the linguistic index of New Zealand national identity.

My guess is that even where postcolonial guilt vis-à-vis the dominance of English is not at play, we may find that the cultural allure of English as an index of Anglo-American culture may wane. The Trump presidency has certainly frayed international perceptions of the United States, from Trump offending the Danish with proposals to purchase Greenland, to launching a trade war with China and calling African states "shitholes" (Watkins and Phillip 2018), all while hurtling democracy - the hallmark of American foreign policy - into crisis. Brexit too will decrease British influence in Europe, and is also viewed by some as a product of arrogant and circumspect British exceptionalism. This means the impacts of these historic events may not be purely political. If the cultural currency of Anglo-American products wanes as a result of shifting global perceptions of dominant English-speaking societies, then so too might the cultural currency of the English language. This is of course speculation. It does, however, open up an intriguing line of research in language ideology studies, and this chapter indeed shows that evolving ideologies may not necessarily or uniformly pedestalize English. One thing is for sure: all world languages have their day. Latin had it. French had it more recently, too. The next to fall from its throne will at some point be English.

\section{REFERENCES}

Albury, N. J. (2015), 'Collective (White) Memories of Māori Language Loss (or Not)', Language Awareness, 24 (4): 303-15.

Albury, N. J. (2016a), 'Defining Māori Language Revitalisation: A Project in Folk Linguistics', Journal of Sociolinguistics, 20 (3): 287-311.

Albury, N. J. (2016b), 'An Old Problem with New Directions: Māori Language Revitalisation and the Policy Ideas of Youth', Current Issues in Language Planning, 17 (2): 161-78.

Albury, N. J. (2017a), 'Mother Tongues and Languaging in Malaysia: Critical Linguistics under Critical Examination', Language in Society, 46 (4): 567-89.

Albury, N. J. (2017b), 'The Power of Folk Linguistic Knowledge in Language Policy', Language Policy', 16 (2): 209-28.

Albury, N. J. (2018a), “If We Lose Their Language We Lose Our History”: Knowledge and Disposition in Māori Language Acquisition Policy', Journal of Language, Identity \& Education, 17 (2): 69-84, doi:10.1080/15348458.2017.1389281.

Albury, N. J. (2018b), 'Linguistic Landscape and Metalinguistic Talk about Societal Multilingualism', International Journal of Bilingual Education and Bilingualism, 1-17, doi: 10.1080/13670050.2018.1452894.

Albury, N. J. (2018c), 'Multilingualism and Mobility as Collateral Results of Hegemonic Language Policy,' Applied Linguistics, doi: https://doi.org/10.1093/applin/amy054.

Albury, N. J. (2019), 'Beyond Economy and Culture: Language-in-Education Preferences of Malaysian Youth', Current Issues in Language Planning, 1-19, doi:10.1080/14664208.2019 .1680161.

Albury, N. J. (2020), 'Forging and Negating Diasporic Linguistic Citizenship in Ethnocratic Malaysia', Lingua, doi:https://doi.org/10.1016/j.lingua.2018.08.003.

Albury, N. J. and L. Carter. (2017), 'A Typology of Arguments For and Against Bilingual Placenaming in Aotearoa New Zealand', Journal of Multilingual and Multicultural Development, 38 (9): 831-42. 
Andaya, B. W. and L. Y. Andaya. (2016), A History of Malaysia, London: Palgrave Macmillan. Belich, J. (2001), Paradise Reforged: A History of the New Zealanders from the 1880s to the Year 2000, Auckland: Allen Lane/Penguin Press.

Benton, R. A. (2017), 'Mauri or Mirage? The Status of the Māori Language in Aotearoa New Zealand in the Third Millennium', in A. B. M. Tsui and J. W. Tollefson (eds), Language Policy, Culture, and Identity in Asian Contexts, 163-82, New York: Routledge.

Bishop, M. (2018), 'China Crisis?', in C. Hay and T. Hunt (eds), The Coming Crisis, 103-11, Cham: Springer International Publishing.

Blackledge, A. (2000), 'Monolingual Ideologies in Multilingual States: Language, Hegemony and Social Justice in Western Liberal Democracies', Estudios de Sociolingüistica, 1 (2): $25-45$.

Blommaert, J. (2006), 'Language Ideology', in K. Brown (ed.), Encyclopedia of Language \& Linguistics, 2nd Eedn (vol. 6), 510-22, Amsterdam: Elsevier.

Canagarajah, S. (2005), 'Reconstructing Local Knowledge, Reconfiguring Language Studies', in A. S. Canagarajah (ed.), Reclaiming the Local in Language Policy and Practice, 3-24, Mahwah: Lawrence Erlbaum.

Coluzzi, P. (2012), 'Modernity and Globalisation: Is the Presence of English and of Cultural Products in English a Sign of Linguistic and Cultural Imperialism? Results of a Study Conducted in Brunei Darussalam and Malaysia', Journal of Multilingual and Multicultural Development, 33 (2): 117-31.

Davey, J. A. and R. A. Kearns. (1994), 'Special Needs Versus the 'Level Playing-field': Recent Developments in Housing Policy for Indigenous People in New Zealand', Journal of Rural Studies, 10 (1): 73-82.

de Bres, J. (2011), 'Promoting the Māori Language to Non-Māori: Evaluating the New Zealand Government's Approach', Language Policy, 10 (4): 361-76.

Foucault, M. (1980), Power/knowledge: Selected Interviews and Other Writings, 1972-1977, Brighton: Pantheon.

Gerritsen, M., F. van Meurs, B. Planken and H. Korzilius, (2016), 'A Reconsideration of the Status of English in the Netherlands within the Kachruvian Three Circles Model', World Englishes, 35 (3): 457-74.

Gill, S. K. (2005), 'Language Policy in Malaysia: Reversing Direction', Language Policy, 4 (3): 241-60.

Gill, S. K. (2013), Language Policy Challenges in Multi-Ethnic Malaysia, Dordrecht: Springer.

Goh, D. P., M. Gabrielpillai, P. Holden and G. C. Khoo (2009), Race and Multiculturalism in Malaysia and Singapore, London: Routledge.

Govindan, I. V. and S. Pillai (2017), 'English Question Forms Used by Young Malaysian Indians', The English Teacher, 38:74-9.

Hamayotsu, K. (2014), 'Towards a More Democratic Regime and Society? The Politics of Faith and Ethnicity in a Transitional Multi-ethnic MalaysiaEnglish Question Forms Used by Young Malaysian Indians', Journal of Current Southeast Asian Affairs, 32 (2): 61-88.

Hiss, F. (2013), 'Tromsø as a "Sámi Town”? - Language Ideologies, Attitudes, and Debates Surrounding Bilingual Language Policies', Language Policy, 12 (2): 177-96.

Hornberger, N. (2002), 'Multilingual Language Policies and the Continua of Biliteracy: An Ecological Approach', Language Policy, 1 (1): 27-51.

Jenkins, J., A. Cogo and M. Dewey (2011), 'Review of Developments in Research into English as a Lingua Franca', Language Teaching, 44 (3): 281-315.

Jin, X., D. D. Li and S. Wu (2016), 'How Will China Shape the World Economy?', China Economic Review, 40: 272-80. 
Johnson, D. C. (2009), 'Ethnography of Language Policy',Language Policy, 8 (2): 139-59.

King, K., L. Fogle and A. Logan-Terry (2008), 'Family Language Policy', Language and Linguistics Compass, 2 (5): 907-22.

Li, W. (1994), Three Generations, Two Languages, One Family: Language Choice and Language Shift in a Chinese Community in Britain, Clevedon: Multilingual Matters.

Malaysiadigest.com. A Vernacular School Where Malay Outnumber Chinese Pupils. (2 October 2015), Malaysiadigest.com.

Malaysian Investment Development Authority (2019). Why Malaysia. http://www.mida.gov.my/ home/why-malaysia/posts/ (accessed 30 April 2016).

The-Malign-Hzeempetenee-of the-British-Ruling Glass?-(-17-Jantary-2019), The-New-York-Times.-

May, S. (2003), 'Rearticulating the Case for Minority Language Rights', Current Issues in Language Planning, 4 (2): 95-125.

New Zealand History Online (2012), 'Impact - Maori and the Second World War', http://www .nzhistory.net.nz/war/maori-and-the-second-world-war/impact.

Noor, N. M. and C.-H Leong (2013), 'Multiculturalism in Malaysia and Singapore: Contesting Models', International Journal of Intercultural Relations, 37 (6): 714-26.

Orange, C. (2011), The Treaty of Waitangi, Wellington: Bridget Williams Books.

Phillipson, R. (2003), English-Only Europe? Challenging Language Policy, London and New York: Routledge.

Phooi-Yan Lee, D. and S.-H Ting (2016), 'Tracing Ethnic Socialisation of Chinese in Malaysia to Chinese-medium School', Global Chinese (vol. 2), 2 (2): 163-87.

Piller, I. and J. Cho (2013), 'Neoliberalism as Language Policy', Language in Society, 42 (1): 23-44.

Preston, D. (2005), 'What Is Folk Linguistics? Why Should You Care?', Lingua Posnaniensis: Czasopismo Poświecone Językoznawstwu Porównawczemu i Ogólnemu, 47: 143-62.

Preston, D. (2011), 'Methods in (Applied) Folk Linguistics: Getting into the Minds of the Folk', AILA Review, 24 (1): 15-39.

Pyvis, D. and A. Chapman (2007), 'Why University Students Choose an International Education: A Case Study in Malaysia', International Journal of Educational Development, 27 (2): $235-46$.

Ramanathan, V. (2005), The English-Vernacular Divide: Postcolonial Language Politics and Practice (vol. 49), Clevedon: Multilingual Matters.

Ricento, T. (2015), 'Political Economy and English as a "Global” Language', in T. Ricento (ed.), Language Policy and Political Economy: English in a Global Context, 27-47, Oxford and New York: Oxford University Press.

Ridge, B. (2004), 'Bangsa Malaysia and Recent Malaysian English Language Policies', Current Issues in Language Planning, 5 (4): 407-23.

Rumsey, A. (1990), 'Wording, Meaning, and Linguistic Ideology', American Anthropologist, $92(2): 346-61$.

Sadka, E. (1968), The Protected Malay States, 1874-1895, Kuala Lumpur: University of Malaya Press.

Smart, B. (ed.). (1999), Resisting McDonaldization, London: Sage.

Smith, L. T. (1999), Decolonizing Methodologies: Research and Indigenous Peoples, London: Zed Books.

Sodian, B. and S. Kristen. (2010), 'Theory of Mind', in B. Glatzeder, V. Goel and A. Müller (eds), Towards a Theory of Thinking: Building Blocks for a Conceptual Framework, 189-201, Heilderberg: Springer.

Spolsky, B. (2009), Language Management, Cambridge: Cambridge University Press. 
Todal, J. (2003), 'The Sámi School System in Norway and International Cooperation', Comparative Education, 39 (2): 185-92.

Toki, V. (2017), 'Maori Seeking Self-determination or Tino Rangatiratanga? A Note'. Journal of Maori and Indigenous Issues, 5: 134-44.

'Trump decries immigrants from 'shithole countries' coming to US' (12 January 2018), CNN.

Van Meijl, T. (2006), 'Multiple Identifications and the Dialogical Self: Urban Maori Youngsters and the Cultural Renaissance', Journal of the Royal Anthropological Institute, 12 (4): 917-33.

Veracini, L. (2014), 'Understanding Colonialism and Settler Colonialism as Distinct Formations', Interventions, 16 (5): 615-33.

Waitangi Tribunal (2011), 'Wai 262 Waitangi Tribunal Report 2011', Wellington: Legislation Direct.

Watkins, E. and B. Phillip (2018). https://edition.cnn.com/2018/01/11/politics/immigrants-shith ole-countries-trump/index.html

The World Doesn't Hate Trump's America as Much as People Think. (9 July 2019), The Washington Post.

Wright, S. (2003), Language Policy and Language Planning: From Nationalism to Globalisation, Basingstoke: Palgrave Macmillan.

Yin, J. T. Y. (2015), 'Malay Parents' Persective on Admission of Their Children to Chinese Primary School in Kelantan, Malaysia', Researchers World, 6 (1): 26-30.

Yotsumoto, Y. (2019), 'Revitalization of the Ainu Language: Japanese Government Efforts', in S. D. Brunn and R. Kehrein (eds), Handbook of the Changing World Language Map, 1-17, Cham: Springer International Publishing.

Yow, C. H. (2017), 'Ethnic Chinese in Malaysian Citizenship: Gridlocked in Historical Formation and Political Hierarchy', Asian Ethnicity, 18 (3): 277-95.

Zhou, M. and W. Xiaomei (2017), 'Introduction: Understanding Language Management and Multilingualism in Malaysia', International Journal of the Sociology of Language, 244: 1-16. 